\title{
Loan Clientele of State University and Land-Grant College Libraries
}

The librarian of the University of Arkansas has studied the practices of a group of libraries, in the thought that the results might help in defining their clientele.

$\mathrm{T}$ HE FIRST FUNCTION of a college or university is to provide an education for its matriculated students. Beyond that each has a certain amount of public responsibility, whatever its source of income. In particular, colleges and universities which receive the major portion of their income from public tax sources have other direct and implied obligations to the people of the state which gives them support. The state university or land-grant college usually assumes these obligations in the form of extension agencies, by making its research facilities, staff, and publications available freely to the state, and by other means. The extent to which such institutions assume these responsibilties is dependent upon many factors, such as adequacy of support, obligations as expressed by establishing or enabling law, traditions, policy of governing boards, awareness of administrative and teaching staffs, and the measure in which other state agencies exist for the given purpose.

What, if any, is the off-campus responsibility of the library of the state-supported institution in the matter of making its facilities available to the citizens of the state? As an ancillary agency it is, of course, dependent regarding its policies in this respect upon those of the institution. Its first function is to supply the material and services needed in connection with the instructional program. But does it have definite responsibilities beyond the campus environs? Is it under obligation to lend books needed by people out in the state, if such books cannot be obtained readily elsewhere in the state? Judging by practices and stated policies, relatively few such libraries face the obligation squarely, if we grant that it exists, and in organized fashion. Moreover, there is no general agreement as to giving services to local communities beyond the campus.

Early in 1944, in an attempt to ascertain practices followed by this group of libraries defining their loan clientele, other than for institutional staff members and regular students, questionnaires were sent to the seventy-one state universities and land-grant colleges of the United States. The following is a summary and analysis of replies received from sixty-seven libraries.

\section{Families of Staff}

All libraries give some type of service to immediate members of the families of staff or faculty members. As a general rule, fourteen confine their loan services to the husbands or wives of staff members, viz., Arizona, Arkansas, California (Berkeley and Los Angeles), Delaware, Illinois, Michigan State, Minnesota, Oklahoma A. and M., Oregon State, Tennessee, Washington, West Virginia, Wisconsin. Practices in others vary widely, with the majority limiting loans to the immediate family only. Typical examples of varying practices in- 
clude: privileges to others upon special request ( $\mathrm{Utah}$ ); children and visiting relatives included (Iowa); anyone served but children (Purdue) ; all living in household accommodated (Georgia); borrowers' cards issued to children (Alabama Polytechnic Institute); borrowers' cards not issued to those under eighteen (Oregon); anyone but children below high school age included (Rutgers); all employees of the university and their families served (Colorado); anyone regardless of relationship permitted to borrow (New Mexico) ; a son or daughter who has finished high school and college and is living at home allowed to draw books by signing his or her father's name if the latter has made a special request (Michigan).

\section{Part-Time Students}

With the exception of Arkansas, all libraries report that they give part-time or special students the same loan privileges as regular students who are taking full-time schedules. At Arkansas it was found advisable to limit these loans somewhat, in order to correct abuses of privileges. However, in actual practice, for the majority of such students, this regulation is applied only when necessary to correct flagrant misuse, such as the borrowing of many recreational books for other members of the family, for neighbors, and for friends. Since students who are registered for only a small portion of the normal load are usually local residents, paying only a nominal fee, it is difficult to see how libraries which deny loan privileges to citizens of the local communities can justify granting full loan privileges to such students. The practice is known to cause ill will on the part of others who cannot withdraw books.

\section{Correspondence Students}

In institutions where organized extension courses are given, the usual practice is for the student to obtain the major part of the material needed through the office of the correspondence or extension division. Many libraries report, however, that direct supplementary loans are made in some form or other. Thirty loan directly to such students both locally and by mail; two loan only to local students; nineteen make no direct loans; sixteen institutions do not offer correspondence courses. Several libraries which do not loan directly will make loans only by regular interlibrary loan. When there is a library extension agency all such loans usually are handled by this division of the library. Most libraries will supply material freely to the extension division of the institution for the use of correspondence students. A small number, however, prefer to make all such loans directly through library facilities rather than through the extension division offices. Two libraries charge a one-dollar fee for a library card; two require deposits, one of which makes a service charge of twenty-five cents for each book borrowed.

\section{Nanregistered Graduate Students}

Graduate students who have completed residential work for degrees and are preparing theses or dissertations may, in general, expect help from the library of their alma mater in the form of free loans of material. Fifty-one of the sixty-two giving graduate work make direct loans as necessary, though several prefer to use the facilities of interlibrary loan only. Eleven will lend only in this way. Such circulation usually is without charge, but a few, such as Texas and Washington State, require deposits. At Tennessee local county students pay a quarterly fee of $\$ \mathrm{I} .50$ for such borrowing privileges. At California the fee is $\$ 6$ per year and at Washington $\$ 3$.

\section{Persons without College Connection}

For practical purposes it may be said that all libraries will and do make direct loans, 
on occasion and by some arrangement, to individuals who have no official connection with the college or university. Four institutions report definitely that they do not make such loans, but it may safely be assumed that these libraries would not deny an occasional direct loan if conditions made the action highly desirable and no other means were available, even though the general policy may be to lend only through regular interlibrary loan channels. As a solution to the general question, however, the occasional or "exception to the rule" loan means little. The important point remains: what is the extent or coverage of off-campus loans throughout the state?

There is little or no uniformity of practice among the group of libraries as to lending to noncollege applicants. The most often expressed replies to the question of direct loans to outsiders are: "occasionally," "sometimes," "by special permission," “on proper recommendation," "few calls," "no definite policy," "not often," or "exceptions made by the librarian." From this a general conclusion may be drawn to the effect that the majority of libraries, while willing to make such loans, have no definite policy or machinery for handling them as a matter of routine. Theoretically, all citizens of the state who have special need for the services of their college or university library may receive them, if they can discover how. The universal American library practice of interlibrary loan will usually bring the desired results, but the prospective borrower may have some difficulty in finding a local library through which to make application. States and regions having poor local library coverage may thus expect little assistance from this source. These, then, have the greater need for some agency which will bridge the gap between the people and the resources of the college library, as supplementary to those existing in local communities and those of state-wide agencies organized for the direct purpose of giving extension library service.

When direct loans are made there usually is no charge, insofar as the lending library is concerned, other than for postage. Seven libraries, or the extension division through which local or state-wide loans are made, charge a fee ranging from ten cents per book to seven dollars per year. Eight require a deposit ranging from the price of the book to six dollars per year for borrowing privileges.

Twenty-five libraries, or 37 per cent of those reporting, as a general rule limit direct loans to local communities or special groups therein. Nine of these twenty-five lend only to special local groups, such as ministers, teachers, alumni, and doctors. Thirty will make direct loans to applicants by mail, usually with a state limit, under conditions ranging from free service to anyone who applies, to a requirement for a fee or a deposit; twenty-five will not lend directly to individuals by mail. Some few who do not lend by mail but who make over-thecounter loans to local groups, will also make such loans to others provided proper identification is furnished.

Despite the possible desirability and feasibility of the direct lending of books freely to residents of the local community, it is difficult to see the logic of such an arrangement unless the same privilege is at least potentially available to all residents of the state. Under such an arrangement people outside the local community will have a justifiable complaint that partiality is shown to local residents. It should also be pointed out here that when the college or university gives loan services freely to all local residents, particularly in a medium-sized town, much of the incentive for adequate support of the local public library is destroyed. At least one instance is definitely known where this is an important factor, the public library board being opposed to such policies 
for the reason stated. It may be assumed that this argument may be advanced logically in many other localities.

Those residing within calling distance of the campus pay no more proportionately in taxes toward the operating expenses of the institution than do those residing in the most distant section of the state. As a matter of fact, they actually are in position to receive many benefits which distance denies to others. Their children may commute to and from the campus at a considerable saving in expense; they are in position to receive more prompt assistance, more often, from service divisions of the college, than is possible to others. Do local residents then have the right to expect or demand library services which are ordinarily available only to students and staff? (From a practical standpoint this question may be regarded only as theoretical. It is recognized that many libraries can and do give these services without the complications referred to, the justification being that it is better to be illogical in this respect than to deny local service which funds, resources, and personnel will not permit to be extended to all.)

The following statements or quotations from selected libraries will serve as typical illustrations of the wide variation in practices and may possibly be of some assistance to other libraries when considering changes in definitions for clientele.

Loans generally limited to local community "within a radius of seven miles," with a fee of one dollar for card; ministers and teachers have courtesy cards (Alabama Polytechnic Institute). "Our loan policy to nonstudents and faculty is governed more by the demonstrated needs of individual cases rather than by definite and strict rules. We make loans by mail to state residents when local libraries cannot supply the materials; we make interlibrary loans; we loan to local individuals with serious intentions who are doing research, etc., and who find the public libraries inadequate" (University of Arizona). Special loans made to individuals by mail only when interlibrary loan services of a local library not available. Local ministers, teachers, and alumni given courtesy borrowing privileges; other special local groups by fee (University of Arkansas). "Residents of Berkeley and the San Francisco Bay region may use the library for reference. If any desire to borrow books, a $\$ 6.00$ fee per year is collected. If a person in the community has urgent need for an individual volume, arrangements might be made to borrow this volume by leaving a cash deposit equal to the value of the book. Privileges to borrow books by individuals are restricted to the local community, that is, the so-called San Francisco Bay region. . . . Privileges of using the library and borrowing books without fee assessments are extended to faculties of local institutions of higher learning" (University of California, Berkeley). Loans made to local individuals at ten cents per loan (Colorado State).

"Students in the public schools have the privilege of using books in the university library only" (University of Georgia). Loans generally limited to local community; "home use only for special work using nonpopular material" (University of Illinois). "Persons must be known to us or identified. Occasionally we have asked for a cash deposit, never a fee" (Purdue). "Ordinarily we lend only through interlibrary loans, but some exceptions are made" (Iowa State). Loans made within the city; "outside requests are handled by the extension division" (University of Kansas). Loans made throughout the state by deposit amounting to the price of the book (University of Kentucky). "In general we lend to anyone" (University of Maine). Locally, "over the counter upon satisfactory identification" (University of Maryland). "Exceptions 
are sometimes made by the librarian, and borrowing privileges are granted to individuals recommended in writing by wellknown industrial firms, or librarians, or by a professor" (M.I.T.). "Anyone desiring material from the university library must apply for it through the local library. All such questions are handled by interlibrary loan" (University of Michigan). "Although officially we do not lend to individuals not connected with the University of Minnesota program, we will grant loan privileges to persons with a legitimate need for the services of our library and with some knowledge or acquaintanceship among members of the staff of the University of Minnesota. Thus, a great many local professional people are given special permission to use the library and, occasionally, former students recommended by a faculty member are extended the same privilege" (University of Minnesota). Cash deposit of five dollars (Montana State University).

Unique among colleges and universities of this group and by contract agreement with the town, extending over a long period of years, all citizens of the town have the same general library privileges as students and faculty (University of New Hampshire). "Only the postage is paid, if books are loaned by mail. Otherwise, only a name and address are necessary to borrow a book" (University of North Dakota). "There are comparatively few public libraries in this state which makes it impossible in many cases to send books through the usual interlibrary loan channels when requested. We, therefore, lend many books each year directly to individuals in all parts of the state, particularly if such books are of the ordinary trade type and can be easily replaced" (Oklahoma Agricultural and Mechanical College). "Professional people in Corvallis, ministers, teachers, physicians, lawyers, and the like; no charge made" (Oregon State).
Such loans handled by division of university extension: "Those individuals who desire to make use of the library facilities provided for university students will be entitled to the same privileges. These privileges are personal use of catalogues, bibliographies, and other reference tools in the building itself, the personal assistance of the regular library staff, and the borrowing of books in accordance with the regulations governing their use by students and faculty. The fee for this service is $\$ 7.00$ for one year (\$3.50 for six months)." A fee of twenty-five cents is charged for the occasional loan (University of Tennessee). Loans made to all persons not connected with the college for a deposit of six dollars (Agricultural and Mechanical College of Texas). "The library is free to the public for consultation; graduates of the university and others may, upon depositing five dollars with the auditor, secure the privilege of borrowing books not needed for reference or class work" (University of Texas). Local loans made on proper recommendation; restrictions are kept to the minimum. Outside loans are made through the library extension service, which prepares special printed lists of books available but does not necessarily limit loans to such lists; fees are ten cents for one book, twelve cents for two books, fifteen cents for three books, etc. (University of Virginia). With the exception of local clergymen and a few other special groups, who are given free courtesy cards, outside loans are by fee: "\$3.00 a year for nonstudent borrowers. If the card is used less than a year, we refund at the rate of $\$ .75$ a quarter, but do not return the full amount. \$I.OO a year is charged by the extension service for a library card which we honor; $\$ .90$ is held in reserve for the library to draw on for additional copies of books for extension students" (University of Washington). After proof of need of facilities local loans made 
with a deposit of five dollars, otherwise by interlibrary loan channels (University of Wisconsin).

As pointed out previously, the libraries are not always free to make a decision as to whether or not they will offer extensive state-wide service. Local and state conditions preclude any universal uniformity of practices. Likewise, local factors, particularly the location of the institutions, affect policies as to community lending. The smalker the town the more likely that liberal local service can be given. Colleges and universities generous with such lending are more often than not located in small towns and cities. Seventy per cent are located in cities or towns of less than 25,000 population, the average population being 8850 . Thus, the majority are in position to supplement local facilities, if desirable, without large city complications. Cities of twenty thousand and more should be able to give good library service without calling upon the college library extensively.

\section{Alumni}

Few university or college libraries of the group under consideration offer special loans to alumni of the institution. As a general rule an alumnus is offered only the same privileges as are given to other citizens of the state or community. Ten libraries report some type of special service. Arkansas includes alumni among the local group to which it gives courtesy cards upon application, but few have availed themselves of the opportunity. Kentucky loans to alumni residing within the state for two weeks, with privilege of renewal. Massachusetts Institute of Technology reports that "alumni borrowing privileges are on the same basis as student borrowers, with the exception of material in urgent demand and theses, which they may not borrow." Michigan State reports: "Our Friends of the Library group, just started, has a strong alumni membership we aim to favor." Montana State University reports that "If dues are paid to date, alumni may borrow books, with postage paid by alumni secretary's office." At Cornell "all alumni who are permanent residents of Ithaca or vicinity can borrow." Oregon State gives free borrowing privileges to alumni, provided they apply at the library office for a borrower's card. The University of Washington honors membership cards in the alumni association; otherwise, through the extension service with a one-dollar fee for library card. Washington State lends on the same basis as to students; loans by mail are made by library extension. One institution, which declines to be quoted by name, lends to alumni whose dues are paid up in the alumni association.

\section{Direct Cooperation with State Library Agencies}

In reply to a query: "Do you cooperate directly with your state extension agency, such as state library or state library commission, to furnish material for state-wide adult reading programs?" twenty-two replied in the affirmative. However, few give details of any unusual cooperation, and it is believed that in most instances this cooperation is by informal agreement to loan to each other when requested. Many states apparently do not have active state agencies with which it is possible to cooperate or, at least, which ask for cooperation. A few examples of agreements may be cited: "Unusual demands or requests for highly specialized materials are referred to the university. Likewise, if we receive requests for general materials, we refer them to the library extension division" (University of Georgia). "We forward all requests for material for club programs to the state library" (Michigan State). "Many of our loans are made independently of the commission. Other requests come to us because 
the commission does not have the material. Generally, the commission turns over to us requests they cannot handle" (University of Missouri). The University of North Carolina, which has a very active library extension division, replies: "Yes, when helpful, as we are an extension agency of the state." "If we are not able to supply the material requested, we refer the patron to them and vice versa" (University of North Dakota). "We loan material to the commission but not directly to its patrons" (University of South Dakota). "We cooperate with the Washington State Library in furnishing any material needed in this state. The Pacific Northwest Bibliographic Center is located in this building, and this library is very active in interlibrary loan service" (University of Washington). "Commission on campus and it may borrow special books from university library when necessary. Certain requests are referred to commission from university library" (University of West Virginia). The most definite policy of cooperation or formal agreement is contained in a statement sent out by the State University of Iowa in response to requests:

"The following policy regarding the lending of books and other library material has been agreed upon by the Iowa State Traveling Library, the Iowa State College Library and the State University of Iowa Library: (I) loans to schools and debating teams are to be supplied by the Iowa State Traveling Library at Des Moines; (2) loans to extension students are to be supplied by the library of the institution in which the student is registered for his extension work ...; ; (3) loans to women's clubs and their members are to be supplied by the Iowa State Traveling Library; (4) loans to individuals are to be supplied by the Iowa State Traveling Library, except such technical material as the State Traveling Library may not have, and which is to be found at either the state college library at Ames or the state university library at Iowa City. Your requests for the loan of material should be made through your local library, if there is one in the community."

It may be concluded that when loan services, other than usual interlibrary loans on the part of the land-grant or state university library, are to be given, the most satisfactory method is by a definite library extension agency system. If this agency can be the joint responsibility of the library and the general extension service of the college, so much the better. At least there should be close coordination of services between the two. If there exists in the state a separate library extension agency, such as a public library commission, an agreement should be reached as to the responsibilites of each, so that there will be a minimum in duplication of effort and expense. Furthermore, it is logical that the same type of service be available to all within the state, without favoritism, whether this be free, by fee, or by deposit. 